\title{
Analysis Gender in Entrepreneurship Education: Role of Entrepreneurial Potential and Mindsets on Intention Students in Universities
}

\author{
Lena Ria Bela ${ }^{1}$, Asri Laksmi Riani ${ }^{2}$, Mientasih Indriayu ${ }^{3}$ \\ \{lenariabela@gmail.com ${ }^{1}$, asrilaksmiriani@yahoo.com ${ }^{2}$, mientasihindriayu@yahoo.com ${ }^{3}$ \} \\ Universitas Sebelas Maret, Indonesia ${ }^{1,2,3}$
}

\begin{abstract}
This study aims to find out how gender in entrepreneurship education as a place to study entrepreneurship and the role of entrepreneurial potential and mindset can increase student intention. This research method uses a literature review study, which is a literature review from previous research. Gender inequality that still occurs can be seen from the low contribution of women in the economy, especially entrepreneurship, making gender equality as one of the main goals of sustainable development (Sustainable Development Goals/SDGs) in Indonesia. The process of entrepreneurship education, will provide entrepreneurship knowledge and competencies to someone, this will increase one's entrepreneurial potential and mindset so as to encourage the emergence of entrepreneurial behavior and intentions, in connection with this can also be seen the difference between men and women in entrepreneurship education. The results of several studies of previous research literature show that entrepreneurial potential and mindset have a positive effect on one's intention, while gender has different perceptions related to the context of one's intention.
\end{abstract}

Keywords: Gender, Entrepreneurial Potential, Entrepreneurial Mindset, Intention, Entrepreneurship

\section{Introduction}

Entrepreneurship education is a process that begins with student attention and then continues to interest in entrepreneurship. Finally, students will be motivated to establish their own business after building the competencies needed to own and start a new business. The general purpose of entrepreneurship education and training is to develop a set of entrepreneurial skills, increase entrepreneurial mindset, stimulate entrepreneurial behavior, prepare and assist students' entrepreneurial efforts [1].

This can be a means of observing gender differences in the implementation of entrepreneurship education. Gender refers to relationships between men and women, so gender needs to be a concern in discussions related to gender equality or inequality [2]. Gender equality in Indonesia, including in the main goals of sustainable development (Sustainable Development Goals/SDGs) is contained at Presidential Regulation Number 59 of 2017 concerning the implementation of achieving sustainable development goals, which is written in goal 5: achieving gender equality and empowering women.

Women have a lower contribution than men in entrepreneurship. This gender inequality in entrepreneurship is a subject of continually and intense discussion in academics and everyday 
life [3]. Gender inequality is important for entrepreneurship activities in general, because in understanding social context it is necessary to designate "gender inequality" as an important variable when studying the dynamics of gender inequality in entrepreneurship [4]. Education can reduce the impact of gender inequality so that it will affect the economic growth of a country [5].

Entrepreneurs must have entrepreneurial potential and mindset in themselves, so they will be able to encourage them to conduct entrepreneurial behavior. Entrepreneurial potential is a set of psychological perceptions and self-cognition related to success, confidence and risk, entrepreneurial competence and motivation, which have an impact on intention [6]. Entrepreneurial potential consists of entrepreneurial personality traits and environmental variables that influence one's intention to do business and then use it to analyze gender differences [7].

Personality traits need to be considered and have an influence on the intention to start a new business [8]. Personality traits as one of the key factors that influence one's entrepreneurial intention [9]. Dimensions of personality traits, specifically internal locus of control, need for achievement, risk tolerance, and entrepreneurial alertness can develop entrepreneurial intention [10].

Organization for Economic Cooperation and Development (OECD) identifies three main groups of skills that are widely accepted for entrepreneurs: technical, business management, and personal entrepreneurial skills. Personal entrepreneurial skills consist of: self-control and discipline, risk management, innovation, perseverance, leadership, change management, network development, and strategic thinking skills [11]. Skill is a multidimensional construct that includes cognitive knowledge in the form of what is learned; affectively: emotive feeling also which is practiced; behavior: actions at the strategical, tactics and individual level; and contexture relating to the sector level, occupation, demands, duties and responsibilities [12].

Four categories of entrepreneurial skills proposed by Cell are: idea identification/creation, capitalizing on ideas, traits/behavior, and managerial/leadership skills [13]. The definition of entrepreneurial potential in this study refers to an individual psychological and cognition related entrepreneurial intention to start a new business. Psychological and cognition here refers to one's personality traits and entrepreneurship skills. Entrepreneurial mindset needs attention too.

Strategically entrepreneurial mindset has an important role in encouraging and supporting entrepreneurial thinking. Strategic experts, along with entrepreneurs define entrepreneurial mindset as a need for more strategic thinking, beginning with identifying opportunities to be followed up [14]. Entrepreneurial Mindset can be defined by interpreting the first word 'mindset' and then the word 'entrepreneurial'. Mindset is a structured mental attitude or inclination and can change through mindset, talent and ability are permanent but can be developed. The development of a greater awareness of the mindset can make a person start thinking about taking action and reacting in new ways [15]. Entrepreneurial mindset is a mindset that tends to find, evaluate, and take advantage of entrepreneurial opportunities.

Two important components in the entrepreneurial mindset are elaborating mindset and implementing mindset. Elaborating mindset is an important requirement in developing entrepreneurial mindset, decision making that refers to entrepreneurial behavior will decrease along with the increasing elaborating mindset, meaning that there is only the process of fusing mindset entrepreneurship. Implementing mindset is an entrepreneurial mindset that leads to entrepreneurial behavior [16].

Entrepreneurial intention provides direction to understand the antecedents that predict entrepreneurial action [17]. Entrepreneurial intention, is defined as the intention of individuals to take part in activity that refer to the appearance of new businesses [18]. Entrepreneurial 
intention as a belief in someone with the aim to plan and establish a new business venture consciously in the future or for long-term goals in the future [19].

Entrepreneurial intention can be interpreted as an urge of desire and confidence that comes from the individual (psychologically) to carry out entrepreneurship activities. Two models can be used to predict intentions, namely the entrepreneurial event model (EEM) proposed from Shapero and Sokol, then Ajzen's Theory of Planned Behavior model. Both of them propose intention formation to initiate behavior, but there are differences in how the model treats intention formation and mechanisms related to which intentions are translated into behavior [20].

\section{Research Methods}

The methodology used in this study is a literature review, reviewing from previous studies. The type of literature review method used is systematic literature review [21]. A systematic literature review is a research method that is carried out to identify, evaluate and interpret all research that is relevant to a particular research question, topic area, or interesting phenomenon. There are three main processes in the systematic literature review, namely planning the review, conducting the review, and reporting the review [21].

The three stages of a systematic literature review adopted from Kitchenham \& Charters [21] are: Research questions, Inclusion criteria, and Identification of papers [22]. This study uses the stages of a systematic literature review from Kitchenham and Charters was developed by Wahono [23] through Figure 1.

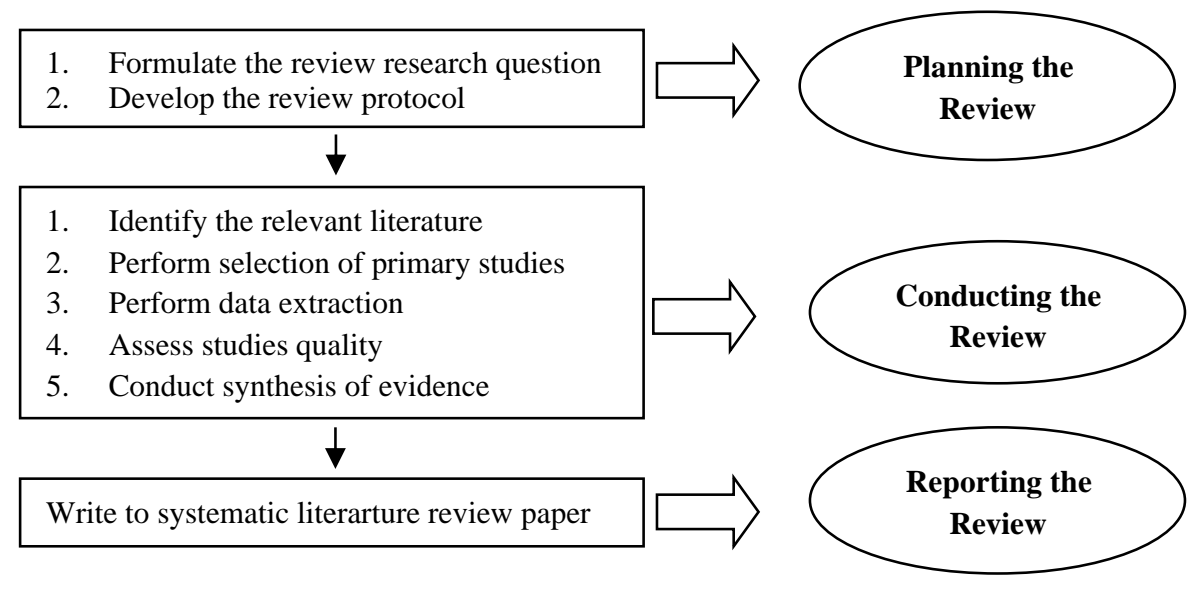

Fig. 1. Stages of systematic literature review (Author processing from Wahono [23]).

\subsection{Planning the Review}

\subsubsection{Formulate the Review's Research Question}

The purpose of this study is to find out how gender relations and the role of entrepreneurial potential and mindset towards intention? The formulation of research question in this study was 
designed using the PICOC formula namely: Population, Intervention, Comparison, Results, and the Context of Kitchenham and Charters [21]. This can be seen in the following Table 1.

Table 1. PICOC Formulas

\begin{tabular}{|l|l|}
\hline \multicolumn{1}{|c|}{ Population } & \multicolumn{1}{|c|}{ Gender, Entrepreneurial Potential, Mindset, dan Intention } \\
\hline Intervention & $\begin{array}{l}\text { 1. Effect of Gender Inequality (male and female) on intention } \\
\text { 2. An important component (Personality Traits and Entrepreneurial } \\
\text { Skill) in entrepreneurial potential and its influence on intentions } \\
\text { Two important things (Elaborating and implementing mindset) } \\
\text { in Entrepreneurial mindset and its influence on intention }\end{array}$ \\
\hline Comparison & -1 \\
\hline \multirow{2}{*}{ Outcomes } & $\begin{array}{l}\text { Accurate predictions related to the influence of gender, } \\
\text { entrepreneurial potential and mindset (through its important } \\
\text { components) on intention }\end{array}$ \\
\hline Context & $\begin{array}{l}\text { Entrepreneurship studies specifically entrepreneurial potential, } \\
\text { mindset, and intention, gender studies in entrepreneurship education }\end{array}$ \\
\hline
\end{tabular}

The research question in this study consists of three, as in the following table 2.

Table 2. Research Question

\begin{tabular}{|c|c|c|}
\hline \multicolumn{2}{|r|}{ Research Questions } & Motivation \\
\hline RQ1 & $\begin{array}{l}\text { How does gender influence } \\
\text { on intention }\end{array}$ & $\begin{array}{l}\text { Gender is always connected with gender } \\
\text { inequality between men and women. Previous } \\
\text { studies have written gender inequality as being } \\
\text { very important in the activities of entrepreneurship } \\
\text { in understanding the social context it is necessary } \\
\text { to designate "gender inequality" as an important } \\
\text { variable when studying the dynamics of gender } \\
\text { inequality in entrepreneurship [4]. Are there } \\
\text { differences between male and female } \\
\text { entrepreneurial intentions? }\end{array}$ \\
\hline RQ2 & $\begin{array}{l}\text { How is the influence of } \\
\text { entrepreneurial potential } \\
\text { which includes personality } \\
\text { traits and entrepreneurial } \\
\text { skills on intention }\end{array}$ & $\begin{array}{l}\text { Entrepreneurial potential variables need to be } \\
\text { calculated based on gender [24]. This shows the } \\
\text { importance of entrepreneurial potential including } \\
\text { personality traits and entrepreneurial skills } \\
\text { assessed by gender, so how is the effect on } \\
\text { intention? }\end{array}$ \\
\hline RQ3 & $\begin{array}{l}\text { How is the influence of } \\
\text { entrepreneurial mindset that } \\
\text { includes elaborating mindset } \\
\text { and implementing mindset } \\
\text { on intention }\end{array}$ & $\begin{array}{l}\text { The importance of an entrepreneurial mindset } \\
\text { based on gender, because both contribute } \\
\text { differently in community development [25]. The } \\
\text { importance of mindset which includes elaborating } \\
\text { mindset and implementing mindset is assessed } \\
\text { based on gender, and how is the effect on } \\
\text { intention? }\end{array}$ \\
\hline
\end{tabular}

Source: Author processing from Wahono [23]. 


\subsubsection{Develop the Review's Protocol}

This stage generally contains 7 elements of procedures and methods in the systematic literature review that will be used, as follows: Background, Research Questions, Search terms, Selection criteria, Quality checklist and procedures, Data extraction strategy, and synthesis strategy [21].

This study uses 5 elements, namely: Research questions, Search terms, Selection criteria, Data extraction strategy, and synthesis strategy.

\subsection{Conducting the Review}

\subsubsection{Identify the Relevant Literature}

Journal searches were conducted from December 2019 until early June 2020. Journal keyword searches were carried out using a search engine:

a. Emerald Journal (https://www.emerald.com/insight).

b. ScienceDirect (https://www.sciencedirect.com).

c. ResearchGate (https://www.researchgate.net).

d. Springer (https://www.springer.com/gp).

e. Scholar Google (https://scholar.google.co.id).

This search engine for keywords is chosen based on the search engine's compatibility with the journals needed to increase the possibility of finding highly relevant articles, because not all keyword search engines publish journals according to the keywords of this study and not all search engines have access to the latest journal publications, for example Cambridge Journals according to research keywords, but only access journal publications from 2012-2013.

The steps of the search string adopted from Wahono [23] are as follows:

a. Identification of search terms from PICOC, especially from Population and Intervention.

b. Identification of search terms from research questions.

c. Identification of terms through search in relevant titles, abstracts and keywords.

d. Identify synonyms, alternative spellings and antonyms of the search term.

\subsubsection{Perform Selection of Primary Studies}

The criteria included in this research are previous literature review studies related to existing variables namely gender, entrepreneurial potential and mindset of intention. The journal publication years used in this study were 2006 to 2020. The oldest journal publications were 2006 and the latest 2020. The first search resulted in 392 journals, titles and abstracts respectively evaluated and 356 rejected because they were not relevant to the research question. So, as many as 36 journals that this study used. These criteria are also formulated based on inclusion and exclusion criteria as in table 3.

Table 3. Inclusion and Exclusion Criteria

\begin{tabular}{|l|r|r|}
\hline \multicolumn{1}{|c|}{ Inclusion Criteria } & \multicolumn{1}{c|}{ Exclusion Criteria } \\
\hline a. $\begin{array}{l}\text { Focusing on the influence of gender, } \\
\text { two important components of } \\
\text { entrepreneurial potential and mindset } \\
\text { towards intention. }\end{array}$ & a. $\begin{array}{l}\text { Does not discuss about entrepreneurship } \\
\text { broadly, inhibiting or accelerating factors } \\
\text { that affect gender, entrepreneurial } \\
\text { potential and mindset of intention. }\end{array}$ \\
$\begin{array}{l}\text { b. Focus on topics, determinants, and } \\
\text { research results. }\end{array}$ & b. $\begin{array}{l}\text { Not focusing model or method used in } \\
\text { researchers. }\end{array}$ \\
\hline
\end{tabular}


\begin{tabular}{l|ll} 
c. Related experience through education & c. Do not have experience in terms of
\end{tabular} and entrepreneurship training. education and entrepreneurship training.

Source: Author processing from Wahono [23].

Based on the criteria described, the following table shows the distribution of the selection of the main study of this study. Attached is table 4. Distribution of the selection of the main studies by topic, determinants, and results

\subsubsection{Perform Data Extraction}

This stage is carried out by selecting the main study and then extracting it so that the data is collected and able to answer the research questions. The data extraction design in this study uses five properties to answer the research questions in Table 5.

Table 5. Mapping Five Extracted Data Properties to the Research Question

\begin{tabular}{|l|c|}
\hline \multicolumn{1}{|c|}{ Property } & Research Question \\
\hline Researchers and Publications & RQ, RQ2, RQ3 \\
\hline Research Trends and Topics & RQ1 \\
\hline Gender of intention & RQ1 \\
\hline Entrepreneurial potential of intention & RQ2 \\
\hline Entrepreneurial mindset of intention & RQ3 \\
\hline
\end{tabular}

Source: Author processing from Wahono [23].

\subsubsection{Assess Studies Quality and Data Synthesis}

Assess studies quality, namely studies conducted to be a reference in interpreting findings on synthesis and to strengthen the conclusions described. Data synthesis aims to analyze, evaluate, and choose the most appropriate method for interpreting the findings in the selected literature. Data synthesis has three forms for interpreting data namely, narrative or qualitative, quantitative, and meta-analysis. This research is a narrative form of synthetic data.

\subsubsection{Reporting the Review}

This stage consists of writing the results of a systematic literature review arranged in the form of scientific journal publications, as well as writing a thesis/thesis/dissertation for chapter 2.

\section{Result and Discussion}

\subsection{RQ1: What is the relationship between gender and intention?}

Learning outcomes with the business plan methodology show negative results, namely women are lower than men [26]. There were no statistical differences between male and female students related to their perceptions of business competence and entrepreneurial intention [1].

Female students have a higher intention to practice online business compared to male students [27]. This study shows that gender has a moderate effect on entrepreneurial intentions because of the enactment of Theory of Planned Behavior (subjective norms, perceived behavioral control and attitudes towards behavior) [28]. 


\subsection{RQ2: How is the entrepreneurial potential relationship that includes personality traits and entrepreneurial skills to intention?}

Entrepreneurial intention is the result of entrepreneurial potential. High entrepreneurial potential will indicate high entrepreneurial intentions, so that the best measure for entrepreneurial potential is through entrepreneurial intention. Changes in attitude and perceived behavioral control are significant and positive effects on entrepreneurial intentions and entrepreneurial potentials. However, this does not apply to subjective norms, so to optimize entrepreneurial potential, it must prioritize increasing the knowledge of the younger generation (changing attitudes) as well placing them in pedagogical situations that are able to develop their skills and competencies related to entrepreneurship activities (to increase perceived behavioral control) [29].

Entrepreneurship potential has an impact on entrepreneurial intention [6]. Entrepreneurial potential as a combination of human capital in the form of knowledge and skills of entrepreneurship, finance and cooperative relationships to build new businesses in a particular business environment. The results show that human capital in the form of knowledge and skills have a positive effect on the development of new businesses and entrepreneurship activities [30].

The influence between personality traits (optimism, self-efficacy, and risk taking) and entrepreneurial intention. The results show that entrepreneurial intention has a positive effect on optimism and self-efficacy, but has a negative effect on risk taking [31]. Research shows that the ability to take risks and perceptions about education do not have a significant effect on entrepreneurial intention [32]. A person's psychological characteristics or personality traits have a positive and significant effect on entrepreneurial intention through entrepreneurship training [33]. Personality traits can influence the formation of entrepreneurial intention, and tend to act indirectly by influencing attitudes and perceived control [20].

Women who increasingly feel skilled or have skills, they will tend to take risks, then significantly influence entrepreneurial intention [7]. Entrepreneurial skills are the main factors determining attitude and perceived control, this attitude will determine entrepreneurial intention [34]. Entrepreneurial skills have a positive impact on entrepreneurial intention [35].

\subsection{RQ3: How is the relationship between the entrepreneurial mindset that includes elaborating mindset and implementing mindset towards intention?}

There is a positive relationship between entrepreneurial mindset and entrepreneurial intention [16]. Someone who applies the elaborate mindset and implementing mindset, can cause more cognitive activity so that it will increase the threshold between intention and action. This shows a positive effect between the elaborate mindset and the implementing mindset of intention [36].

\section{Conclusion}

The phenomenon of gender in entrepreneurship activities, especially entrepreneurship education makes gender an important variable in entrepreneurship. Many researchers analyzed the effect of gender on entrepreneurial intention. The results show that gender has different influences or views related to the context of intention. So, gender has an uncertain relationship 
with a person's entrepreneurial intention, statistically gender does not have a significant relationship with entrepreneurial intention, meaning that there is no significant relationship between men and women. Women tend to have negative learning outcomes related to learning with a business plan methodology. Men have less intention to practice online business than women.

Entrepreneurial potential has a positive influence on intention, and to increase entrepreneurial potential, one must improve their entrepreneurial knowledge and skills. The main components of entrepreneurial potential namely personality traits and entrepreneurial skills have a positive influence on intention. Entrepreneurial mindset has a positive influence on intention, the main component of the entrepreneurial mindset that is elaborating and implementing mindset has a positive effect on intention. So, in entrepreneurial education it is necessary to pay attention to one's entrepreneurial potential and mindset, by optimizing the entrepreneurial potential a person is able to have basic entrepreneurial potential, and through an entrepreneurial mindset can become a person's habit in entrepreneurial behavior. It is important for an entrepreneur to have an entrepreneurial potential and a mindset in him to foster entrepreneurial intentions which will then act entrepreneurially.

This study only reviews previous studies in a systematic manner. So, researchers examined how gender in entrepreneurship education as a place to learn entrepreneurship and the role of entrepreneurial potential and mindset can increase the intention of students at the University from various previous studies. This study has not examined more deeply the factors that encourage or hinder the role of entrepreneurial potential and the mindset of a person's intention, factors that influence gender towards a person's intention, things that mediate or intervene between the role of entrepreneurial potential and the mindset of one's intention.

Another limitation, related to the author's extensive efforts in searching the journal literature, may not yet find all the journals relevant to this study in complete. It is hoped that these limitations can be corrected for future research. Future research can further deepen the discussion related to gender in entrepreneurship education, namely the role of entrepreneurial potential and the mindset that can increase or influence student intention. Can also develop a model related to the role of entrepreneurial potential and a mindset towards intention.

\section{References}

[1] M.-L. Kakkonen, "Students' Perceptions of Their Business Competences and Entrepreneurial Intention.," Manag., vol. 6, no. 3, 2011.

[2] UN Women, "Important Concepts Underlying Gender Mainstreaming," United Nation, 2014. [Online]. Available: https://www.un.org/womenwatch/osagi/pdf/factsheet2.pdf.

[3] V. K. Gupta, A. B. Goktan, and G. Gunay, "Gender differences in evaluation of new business opportunity: A stereotype threat perspective," J. Bus. Ventur., vol. 29, no. 2, pp. 273-288, 2014.

[4] B. L. Bastian, B. D. Metcalfe, and M. R. Zali, "Gender inequality: entrepreneurship development in the MENA region," Sustainability, vol. 11, no. 22, p. 6472, 2019.

[5] S. Klasen and F. Lamanna, "The impact of gender inequality in education and employment on economic growth: new evidence for a panel of countries," Fem. Econ., vol. 15, no. 3, pp. 91-132, 2009.

[6] S. C. Santos, A. Caetano, and L. Curral, "Psychosocial aspects of entrepreneurial potential," J. Small Bus. Entrep., vol. 26, no. 6, pp. 661-685, 2013.

[7] A. Ward, B. R. Hernández-Sánchez, and J. C. Sánchez-García, "Entrepreneurial potential and gender effects: the role of personality traits in university students' entrepreneurial intentions," Front. Psychol., vol. 10, p. 2700, 2019.

[8] G. R. Sargani, D. Zhou, T. Mangan, and H. Rajper, "Determinants Of Personality Traits Influence On Entrepreneurial Intentions Among Agricultural Students Evidence From Two Different 
Economies," Eur. J. Bus. Manag. Res., vol. 4, no. 5, 2019.

[9] S. Mujahid, M. S. Mubarik, and N. Naghavi, "Developing entrepreneurial intentions: what matters?," Middle East J. Manag., vol. 7, no. 1, pp. 41-59, 2020.

[10] A. T. Karabulut, "Personality traits on entrepreneurial intention," Procedia-Social Behav. Sci., vol. 229, pp. 12-21, 2016.

[11] P. Hatthakijphong and H.-I. Ting, "Prioritizing successful entrepreneurial skills: An emphasis on the perspectives of entrepreneurs versus aspiring entrepreneurs," Think. Ski. Creat., vol. 34, p. $100603,2019$.

[12] E. Chell, "Review of skill and the entrepreneurial process," Int. J. Entrep. Behav. Res., 2013.

[13] M. S. Shabbir, M. N. M. Shariff, and A. Shahzad, "A conceptual development of entrepreneurial skills and entrepreneurial intentions: A case of IT employees in Pakistan," Int. J. Acad. Res. Bus. Soc. Sci., vol. 6, no. 3, pp. 65-78, 2016.

[14] N. Krueger and F. Sussan, "Person-level entrepreneurial orientation: clues to the'entrepreneurial mindset'?," Int. J. Bus. Glob., vol. 18, no. 3, pp. 382-395, 2017.

[15] L. Bosman, S. Fernhaber, and S. (Online service), Teaching the entrepreneurial mindset to engineers. Springer, 2018.

[16] V. Q. Cao and T. T. T. Ngo, "Linking entrepreneurial intentions and mindset models: A comparative study of public and private universities in Vietnam," Gadjah Mada Int. J. Bus., vol. 21, no. 2, pp. 115-133, 2019.

[17] A. Mamman, I. K. Olaoye, A. M. Abdulrahaman, J. N. Shagari, and O. K. Lekan, "The Influence of Entrepreneurship Education on the Entrepreneurial Intentions of University Students in Katsina State, Nigeria," Acta Univ. Sapientiae, Econ. Bus., vol. 6, no. 1, pp. 21-42, 2018.

[18] I. Syed, J. C. Butler, R. M. Smith, and X. Cao, "From entrepreneurial passion to entrepreneurial intentions: The role of entrepreneurial passion, innovativeness, and curiosity in driving entrepreneurial intentions," Pers. Individ. Dif., vol. 157, p. 109758, 2020.

[19] E. R. Thompson, "Individual entrepreneurial intent: Construct clarification and development of an internationally reliable metric," Entrep. theory Pract., vol. 33, no. 3, pp. 669-694, 2009.

[20] T. Ahmed, V. G. R. Chandran, J. E. Klobas, F. Liñán, and P. Kokkalis, "Entrepreneurship education programmes: How learning, inspiration and resources affect intentions for new venture creation in a developing economy," Int. J. Manag. Educ., vol. 18, no. 1, p. 100327, 2020.

[21] B. Kitchenham and S. Charters, "Guidelines for performing systematic literature reviews in software engineering," 2007.

[22] T. Hall, S. Beecham, D. Bowes, D. Gray, and S. Counsell, "A systematic literature review on fault prediction performance in software engineering," IEEE Trans. Softw. Eng., vol. 38, no. 6, pp. 1276-1304, 2011.

[23] R. S. Wahono, "A systematic literature review of software defect prediction," J. Softw. Eng., vol. 1 , no. 1, pp. 1-16, 2015.

[24] S. Dilli and G. Westerhuis, "How institutions and gender differences in education shape entrepreneurial activity: a cross-national perspective," Small Bus. Econ., vol. 51, no. 2, pp. 371392, 2018.

[25] D. Hyams-Ssekasi, A. Stefan, F. Agboma, and N. Kumar, "Determinants of women's entrepreneurial attitude across European cultures," in Women Entrepreneurs and Strategic Decision Making in the Global Economy, IGI Global, 2019, pp. 63-78.

[26] R. Ferreras-Garcia, A. B. Hernández-Lara, and E. Serradell-López, "Gender and learning results: a study on their relationship in entrepreneurship education and business plans," Stud. High. Educ., pp. 1-16, 2020.

[27] O. A. Suryawirawan, "Theory of Planned Behavior Approach and Gender Differences on Students' Intention to Practice Online Business," JDM (Jurnal Din. Manajemen), vol. 10, no. 2 , pp. 138-147, 2019.

[28] P. E. Onyeukwu and T. Padmavathi, "Gender as a moderator between entrepreneurship intention and its predictors among university graduates in Nigeria and India," African J. Bus. Manag., vol. 13, no. 18, pp. 622-629, 2019.

[29] E. Varamäki, S. Joensuu, E. Tornikoski, and A. Viljamaa, "The development of entrepreneurial 
potential among higher education students," J. small Bus. Enterp. Dev., 2015.

[30] U. Pauli and R. Osowska, "Building entrepreneurial potential abroad-exploring return migrant experience," Int. J. Entrep. Behav. Res., 2019.

[31] E. Abou, E., A., E., M. Hanafi, and O. Ali, I., E., "Entrepreneurial Intentions: The Influence of Individual Factors," Am. Int. J. Bus. Manag., vol. 3, no. 1, 2020.

[32] W. D. N. Madhavika, "Entrepreneurial Intentions of Sri Lankan Undergraduates," WDN Madhavika,"" Entrep. Intentions Sri Lankan Undergraduates"" Int. J. Acad. Res. Bus. Soc. Sci., vol. 9, no. 6, pp. 202-213, 2019.

[33] D. Aji Irawan, A. Q. A Syakur, and H. Maududi, "Entrepreneurial intention of Indonesian migrant workers,” J. Int. Business, Econ. Entrep., vol. 4, no. 2, pp. 19-28, 2019.

[34] F. I. Vega-Gómez, F. J. Miranda González, A. Chamorro Mera, and J. Pérez-Mayo, "Antecedents of Entrepreneurial Skills and Their Influence on the Entrepreneurial Intention of Academics," Sage Open, vol. 10, no. 2, p. 2158244020927411, 2020.

[35] C. Gieure, M. del Mar Benavides-Espinosa, and S. Roig-Dobón, "Entrepreneurial intentions in an international university environment," Int. J. Entrep. Behav. Res., 2019.

[36] J.-E. Mathisen and J. K. Arnulf, "Competing mindsets in entrepreneurship: The cost of doubt," Int. J. Manag. Educ., vol. 11, no. 3, pp. 132-141, 2013. 


\section{Appendix}

Table 4. Distribution of main study selections by topic, determinants, and results

\begin{tabular}{|c|c|c|c|c|c|c|c|c|}
\hline \multirow[b]{2}{*}{ Year } & \multirow[b]{2}{*}{ Author } & \multicolumn{4}{|c|}{ Topic } & \multicolumn{2}{|c|}{ Determinants } & \multirow{2}{*}{$\begin{array}{c}\text { Outcomes } \\
\text { Benefits }\end{array}$} \\
\hline & & Gender & $\begin{array}{l}\text { Entrepreneurial } \\
\text { Potential }\end{array}$ & $\begin{array}{l}\text { Entrepreneurial } \\
\text { Mindset }\end{array}$ & $\begin{array}{l}\text { Entrepreneurial } \\
\text { Intention }\end{array}$ & Context & Definitions & \\
\hline 2006 & Liñán \& Chen & & & & $\mathrm{X}$ & $\mathrm{X}$ & & $\mathrm{X}$ \\
\hline 2009 & $\begin{array}{l}\text { Klasen \& Lamanna } \\
\text { Thompson }\end{array}$ & $\mathrm{X}$ & & & $\mathrm{X}$ & $\mathrm{X}$ & $\mathrm{X}$ & $\begin{array}{l}X \\
X \\
\end{array}$ \\
\hline 2011 & Kakkonen & & & & $\mathrm{X}$ & & $\mathrm{X}$ & $\mathrm{X}$ \\
\hline 2013 & $\begin{array}{l}\text { Chell } \\
\text { Gupta, Goktan \& Gunay } \\
\text { Mathisen \& Arnulf } \\
\text { Santos, Caetano \& Curral }\end{array}$ & $\mathrm{X}$ & $\begin{array}{l}\mathrm{X} \\
\mathrm{X} \\
\end{array}$ & $\mathrm{X}$ & & $\begin{array}{l}X \\
X \\
X \\
X\end{array}$ & & $\begin{array}{l}X \\
X \\
X \\
X\end{array}$ \\
\hline 2014 & UN, Women. & $\mathrm{X}$ & & & & & $\mathrm{X}$ & $\mathrm{X}$ \\
\hline 2015 & Varamäki et al. & & $\mathrm{X}$ & & & $\mathrm{X}$ & & $\mathrm{X}$ \\
\hline 2016 & $\begin{array}{l}\text { Karabulut } \\
\text { Shabbir, Shariff \& Shahzad }\end{array}$ & & $\begin{array}{l}X \\
X\end{array}$ & & & $\begin{array}{l}X \\
X\end{array}$ & & $\begin{array}{l}X \\
X\end{array}$ \\
\hline 2017 & Krueger \& Sussan & & & $\mathrm{X}$ & & & $\mathrm{X}$ & $\mathrm{X}$ \\
\hline 2018 & $\begin{array}{l}\text { Bosman \& Fernhaber } \\
\text { Dilli \& Westerhuis } \\
\text { Mamman et al. } \\
\text { Pauli \& Osowska }\end{array}$ & $\mathrm{X}$ & X & $\mathrm{X}$ & $\mathrm{X}$ & $X$ & $\begin{array}{l}X \\
X \\
X\end{array}$ & $\begin{array}{l}X \\
X \\
X \\
X\end{array}$ \\
\hline 2019 & $\begin{array}{l}\text { Bastian, Metcalfe \& Zali } \\
\text { Cao \& Ngob } \\
\text { Gieure, Benavides-Espinosa \& Dobón } \\
\text { Hatthakijphong \& Ting } \\
\text { Hyams-Ssekasi et al. } \\
\text { Irawan, Syakur \& Maududi } \\
\text { Madhavika, Onyeukwul \& Padmavathi } \\
\text { Sargani et al. } \\
\text { Suryawirawan }\end{array}$ & $\begin{array}{l}X \\
X \\
X\end{array}$ & $\begin{array}{l}X \\
X\end{array}$ & $\mathrm{X}$ & $\begin{array}{l}X \\
X \\
X\end{array}$ & $\begin{array}{l}X \\
X \\
X \\
X \\
X \\
X \\
X \\
X\end{array}$ & $\begin{array}{l}X \\
X \\
X\end{array}$ & $\begin{array}{l}X \\
X \\
X \\
X \\
X \\
X \\
X \\
X \\
X\end{array}$ \\
\hline
\end{tabular}




\begin{tabular}{|c|c|c|c|c|c|c|}
\hline & $\begin{array}{l}\text { Syeda et al. } \\
\text { Ward, Sánchez \& García }\end{array}$ & & $X$ & & & $\begin{array}{l}\mathrm{X} \\
\mathrm{X}\end{array}$ \\
\hline 2020 & $\begin{array}{l}\text { Abou, Hanafi \& Ali } \\
\text { Ahmeda et al. } \\
\text { Garcia, Lara \& López } \\
\text { Gómez et al. } \\
\text { Mujahid, Mubarik \& Naghavi }\end{array}$ & $X$ & $X$ & $\begin{array}{l}X \\
X\end{array}$ & $\begin{array}{l}X \\
X \\
X \\
X \\
X\end{array}$ & $\begin{array}{l}X \\
X \\
X \\
X \\
X\end{array}$ \\
\hline
\end{tabular}

